\title{
Refractory Endometrial Mixed Cell Adenocarcinoma
}

National Cancer Institute

\section{Source}

National Cancer Institute. Refractory Endometrial Mixed Cell Adenocarcinoma. NCI

Thesaurus. Code C158379.

Endometrial mixed cell adenocarcinoma that is resistant to treatment. 